\title{
North Atlantic Subpolar Gyre Warming - Impacts on Greenland Offshore Waters
}

\author{
M. Stein \\ Institut für Seefischerei, Palmaille 9 \\ D-22767 Hamburg, Federal Republic of Germany
}

Stein, M. 2005. North Atlantic subpolar gyre warming - impacts on Greenland offshore waters. J. Northw. Atl. Fish. Sci., 36: 43-54. doi: 10.2960/J.v36.m568

\begin{abstract}
Sea-surface temperature anomalies in the North Atlantic Subpolar Gyre indicate cold conditions in the 1980s and warming from the mid-1990s onwards, with maximum temperatures observed during October 2003. The latter is consistent with air temperatures at Nuuk, Greenland, which document that 2003 was the warmest year since 1950. Ocean temperatures off West Greenland show a significant upward trend $\left(0.096^{\circ} \mathrm{C}^{-1}\right.$ in 0-300 m layer during 1983-2004), which is considerably higher than that for the North Atlantic Basin over the period 1955-2003. Long-term (1964-2004) observations from Fyllas Bank off West Greenland also reveal warm conditions during the 1960s, although the highest temperatures on record are from the recent years of the present century. Geostrophic transports estimated from autumn 2004 hydrographic data suggest increased northward transport of the West Greenland Current. Ocean properties at this time were more saline and up to $2^{\circ} \mathrm{C}$ warmer-than-normal. Volume transports were $+2.4 S v$ in the core of the West Greenland Current, $+0.5 S v$ on the West Greenland shelf, and $-1.9 \mathrm{~Sv}$ in the Baffin Island Current. While the northward (+) transport figures are in the range of the mean October and November transport values (+ 1.6 Sv to + 3.0 Sv), the southward (-) transport figure is considerably smaller than earlier published values $(-3.1 S v$ to $-4.6 \mathrm{~Sv})$.
\end{abstract}

Key words: Baffin Island Current, Davis Strait, volume transports, West Greenland Current.

\section{Introduction}

The North Atlantic Current, an extension of the Gulf Stream, carries warm subtropical waters towards the Northeast Atlantic and circulates northward and eventually westward forming a broad anticlockwise gyre - the Subpolar Gyre (Fig. 1a). The northward heat transport accompanying these waters is partly responsible for the mild climate of northern and northwestern Europe, which is much warmer than the average for these latitudes. A southward flow of cooler waters counterbalances this warm water flow. Along the Subpolar Gyre, pathway modification and cooling of the warm water occurs, and in the west, Labrador Sea Water flows back towards the subtropical gyre as an intermediate depth current.

Greenland and its adjacent waters are located at the northern boundary of the Subpolar Gyre and thus subject to climatic variations within this gyre. Accordingly, the West Greenland Current (WGC), which follows the continental slope off West Greenland and travels northward through Davis Strait (Fig. 1a, b), carries the warming or cooling signals into Baffin Bay to the north of Davis Strait. Cold Arctic waters flow southward through the Strait via the Baffin Island Current (Fig. 1b).

During recent decades, Greenland's air temperatures and offshore waters have been characterized by tremen- dous variation. After the warmer-than-normal 1950s and 1960s, the 1970s, 1980s and early-1990s experienced a series of anomalous cold years (Buch, 2000; Buch et al., 2004; Drinkwater, 2004; Stein, 2004). In contrast to the last three decades of the 1900s, the first years of the new century have not been extremely cold. All years to date during the 2000s have been warmer-than-normal, with 2003 being the warmest year during the past 50 years (Stein, 2005). Is this warming part of the "global warming" as suggested for the world ocean basins by Levitus et al. (2005), or is it a more regional feature (Häkkinen and Rhines, 2004)? While the first authors reveal that a large part of the change in the ocean heat content during the past 50 years (1955-2003) has occurred in the upper $700 \mathrm{~m}$ of the world ocean, and maximum warming is found in the upper $300 \mathrm{~m}$ of the North Atlantic basin $\left(0.354^{\circ} \mathrm{C}\right.$ during 1955-2003; Levitus et al., 2005), Häkkinen and Rhines (2004) conclude from TOPEX/Poseidon altimeter data that subpolar sea-surface height increased during the 1990s, and the geostrophic velocity derived from altimeter data exhibits declining subpolar gyre circulation. Recent oceanographic observations in the WGC system (Stein, 2004; Stein, 2005) point at record warming in the upper layer of this part of the North Atlantic Subpolar Gyre.

The present contribution deals with climatic changes during 1950 to 2004. After discussing the data and methods, the monthly mean sea-surface temperature 


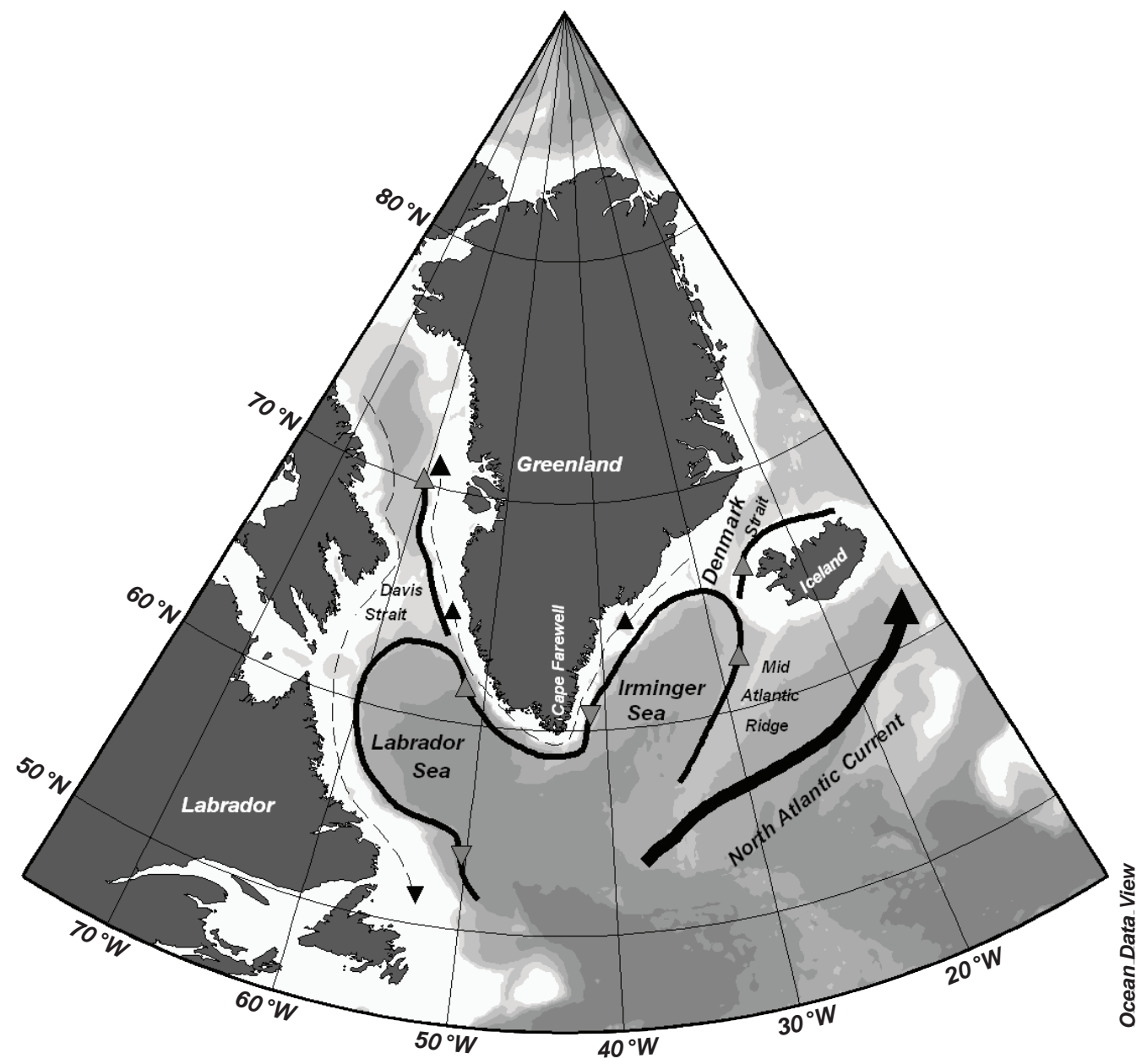

Fig. 1a. Schematic of the subpolar gyre (white area: 0-500 m depth). Bold: warm currents; dashed: cold currents.

anomalies for the Northwest Atlantic during the past 23 years are described. Air temperature anomalies from Nuuk (1950-2004) as proxy for West Greenland climatology (Stein, 2004) are then analyzed, followed by a discussion of sub-surface oceanographic conditions in the WGC. The final section presents temperature and salinity data collected during autumn 2004 in Davis Strait, and volume fluxes are compared to mean conditions and historic data from the 1960 s and 1980 s.

\section{Data and Methods}

Monthly mean sea-surface temperature anomaly (SSTA) data (Fig. 2a-c) for the Northwest Atlantic $\left(40^{\circ} \mathrm{N}-80^{\circ} \mathrm{N}, 70^{\circ} \mathrm{W}-10^{\circ} \mathrm{W}\right)$ were obtained from the IGOSS database http://ingrid.ldgo.columbia.edu/ SOURCES/.IGOSS. At present, SSTA data at 1-degree horizontal resolution are available for the period Decem- ber 1981 to December 2004. The climatology is relative to 1950-79 based upon sea-surface temperatures blended from ship, buoy and bias-corrected satellite data (Reynolds and Smith, 1994).

Data on the atmospheric climate of West Greenland were collected by the Danish Meteorological Institute at Nuuk $\left(64^{\circ} 11^{\prime} \mathrm{N}, 51^{\circ} 44.5^{\prime} \mathrm{W}\right)$ and mutually supplied by the Danish Meteorological Institute in Copenhagen and the Seewetteramt in Hamburg. The air temperature anomalies are referenced to the 1961-90 climatic mean. The presentation of air temperature anomalies from Nuuk by decades was used to discriminate the characteristic features of the decades from the 1950s to 2000s (Fig. 3) following Stein (2004).

Temperature and salinity profiles were taken at ICNAF/NAFO ${ }^{1}$ standard oceanographic stations (Stein,

1 ICNAF = International Commission for the Northwest Atlantic Fisheries (1950-78); NAFO = Northwest Atlantic Fisheries Organization (1979-present). 


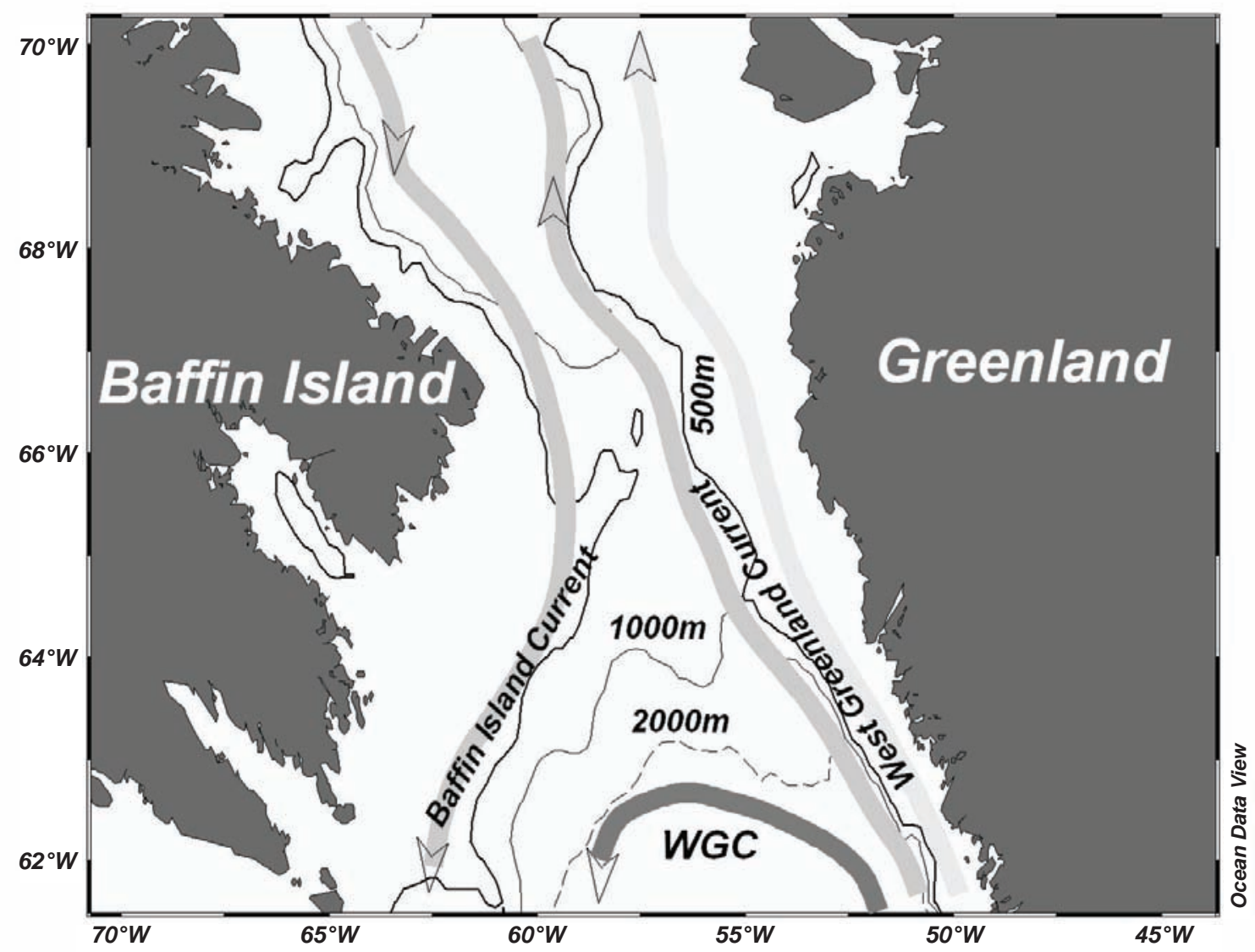

Fig. 1b. Circulation diagram for the Davis Strait region; WGC: branch of West Greenland Current heading west; shelf break component (grey), shelf component (light grey); depth contours for $500 \mathrm{~m}$ (bold), $1000 \mathrm{~m}$ (thin) and $2000 \mathrm{~m}$ (dashed) are given.

1988) during autumn cruises in West Greenland waters by the Institut für Seefischerei in Hamburg, Germany since 1963. These data were used to analyse sub-surface temperature changes at Station 4 of the Fyllas Bank section (Fig. 4) and Station 3 of the Cape Desolation section (Fig. 5,6). A new oceanographic section across the $330 \mathrm{~km}$ wide Davis Strait between Greenland and Canada was occupied during autumn 2004 cruise of FRV Walther Herwig III to obtain geostrophic estimates of water mass transports (for station positions see Table 1 and insert map Fig. 7). Leaving Holsteinsborg/Sisimiut on 31 October, the vessel occupied the 5 NAFO standard stations of the Holsteinsborg section (N1, .., N5; Stein, 1988) and, after reaching Canada's $200 \mathrm{~nm}$ EEZ, continued with 5 stations following historic Canadian RV Hudson positions along $66^{\circ} 30^{\prime} \mathrm{N}(5, \ldots, 1)$. The section was completed on 1 November in the vicinity of Cape Dyer/Baffin Island, Canada. All profiles were obtained with a CTD (SeaBird 911+), salinities were calibrated with water samples derived from a Rosette water sampler, and temperatures were checked against electronic reversing thermometers.
Isopleths of temperature for Fyllas Bank section station 4 and of potential temperature $(\theta)$ for Cape Desolation section station 3 are given in Fig. 4 and 5, respectively. Time series of temperature anomalies at station 3 are provided in Fig. 6. The vertical distribution of temperature and salinity are shown in Fig. 7 and geostrophic currents along the Holsteinsborg-Baffin Island Section in Fig. 8.

Historic hydrographic data from the Davis Strait passage were downloaded from World Data Centre A (http://www.nodc.noaa.gov/OC5/indprod.html). Canadian bottle and CTD data from October 1963, 1965 and 1988 were selected for comparison with our data. These years comprise warm (1960s) and cold (1980s) periods. Geostrophic volume transports are provided in Table 2.

Data analysis, including the geostrophic estimates, and presentation (Fig. 4, 5, 7, 8) were carried out using Ocean Data View (Version 2.1, 2004; Schlitzer, 2004). Where observed depths for adjacent stations did not match, 

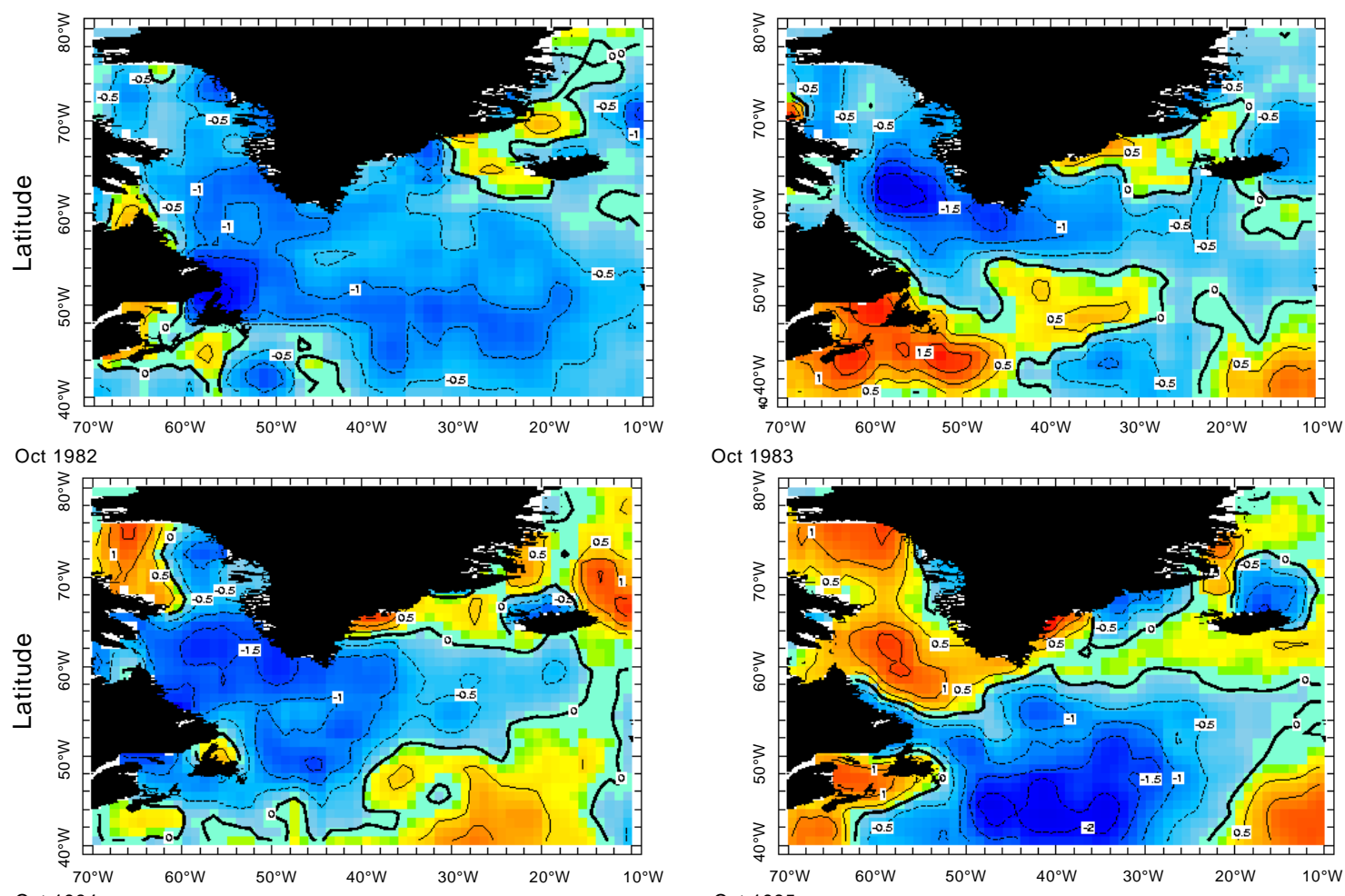

Oct 198
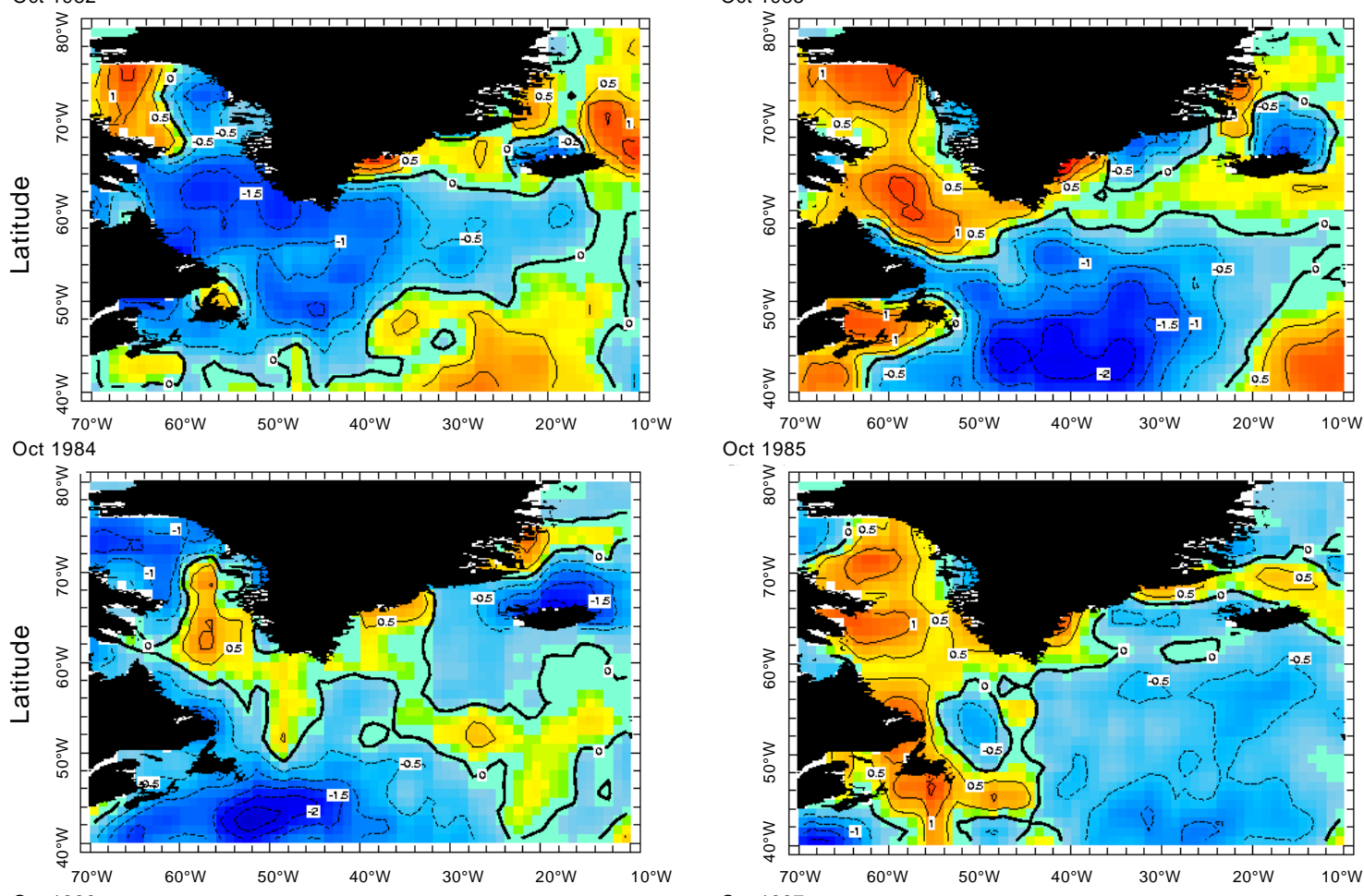
Oct 1985
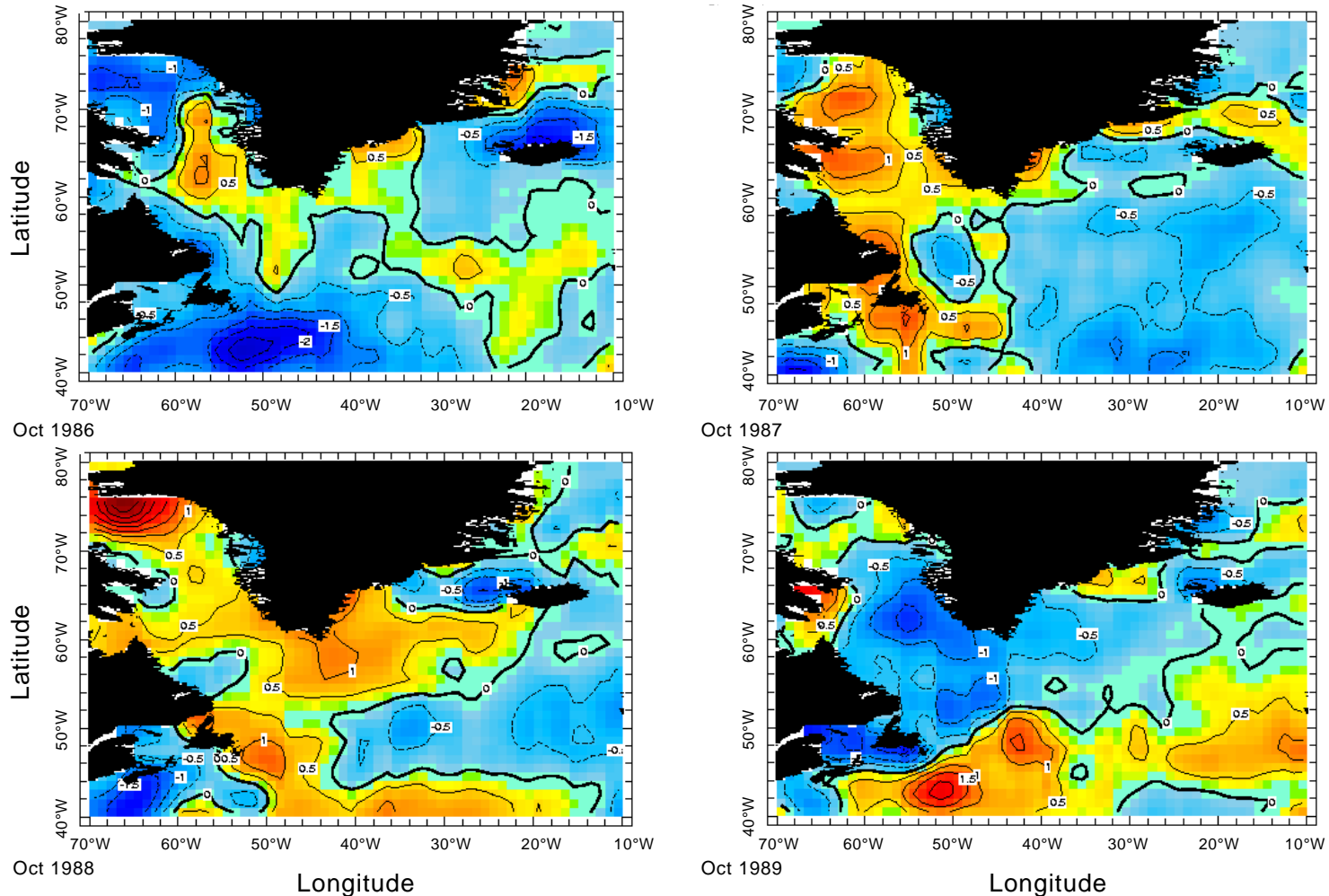

Oct 1987

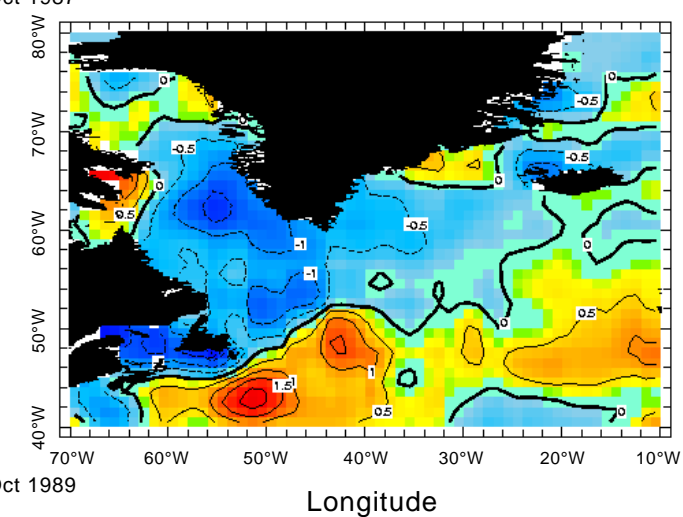

Fig. 2a. Sea-surface temperature anomalies during October $1982-89$. Isothermal contours are in $0.5^{\circ} \mathrm{C}$ intervals. 

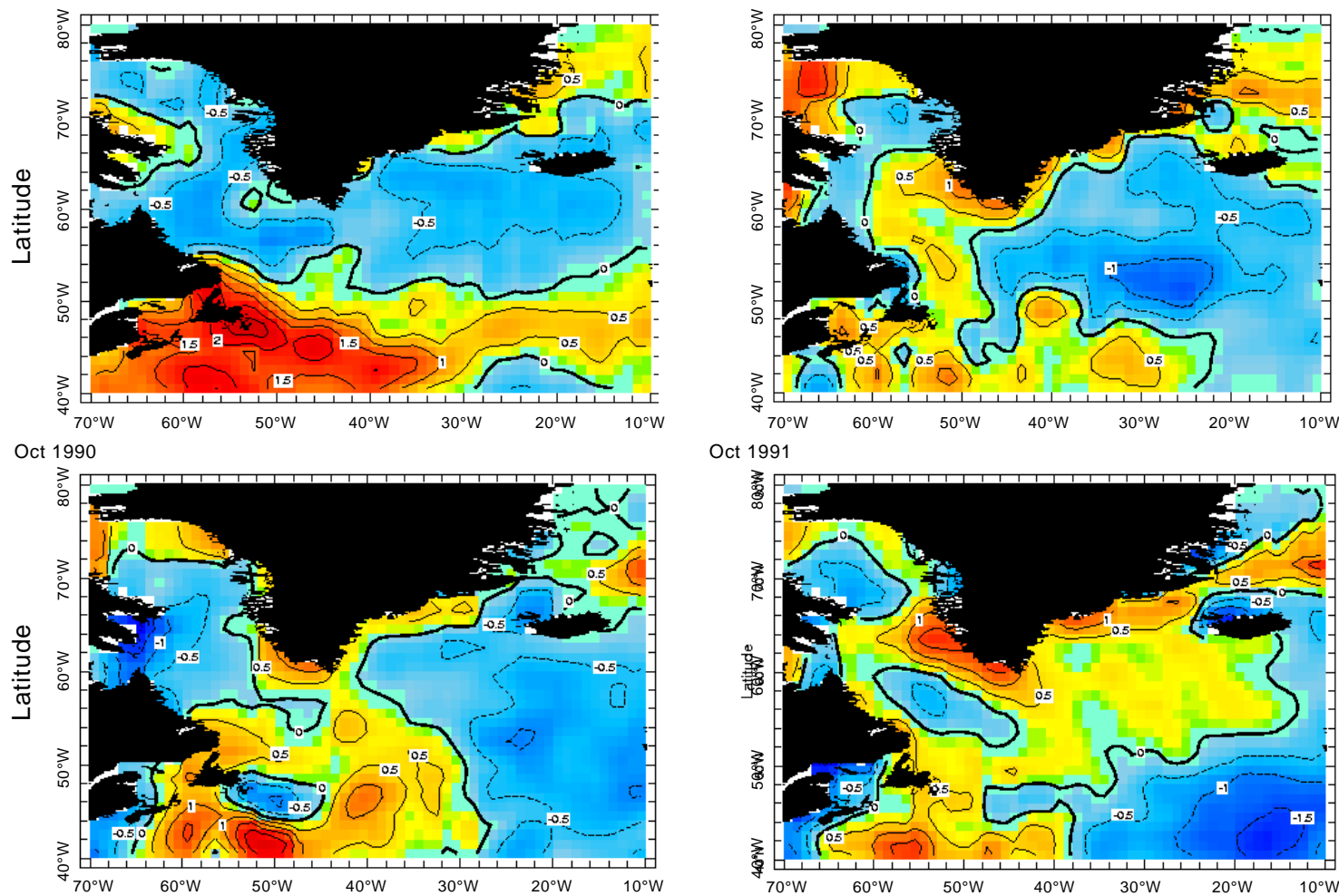

Oct 1991

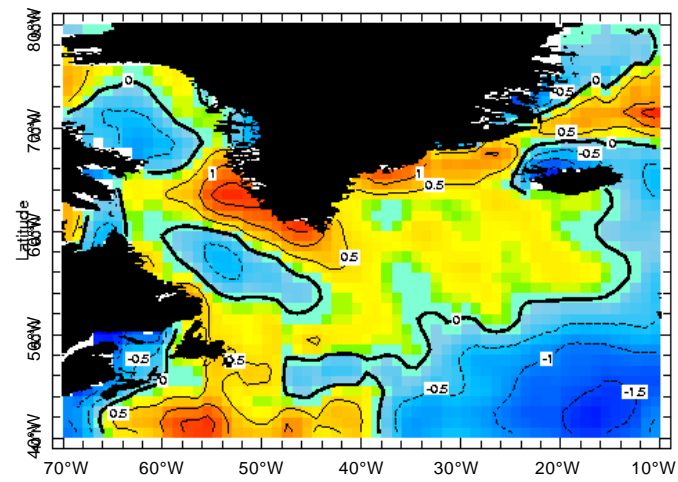

Oct 1992
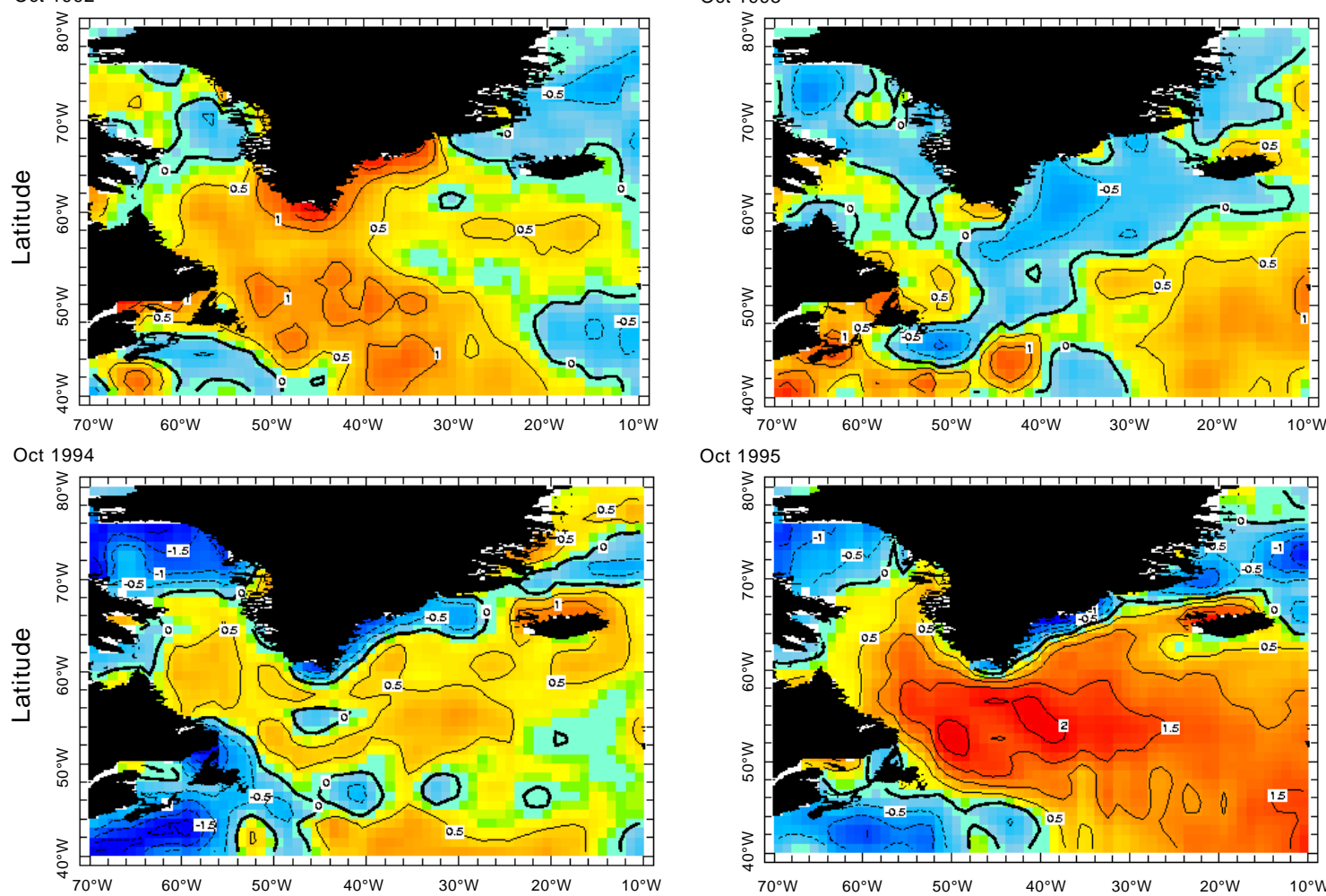

Oct 1996

Longitude

Oct 1995

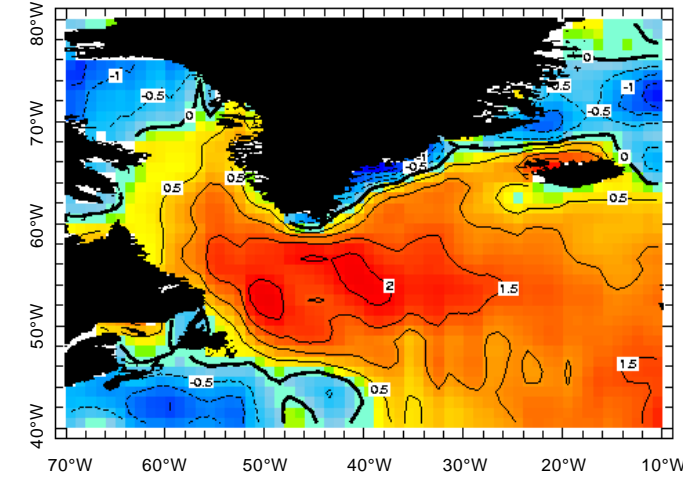

Oct $1997 \quad$ Longitude

Fig. 2b. Sea-surface temperature anomalies during October $1990-97$. Isothermal contours are in $0.5^{\circ} \mathrm{C}$ intervals. 

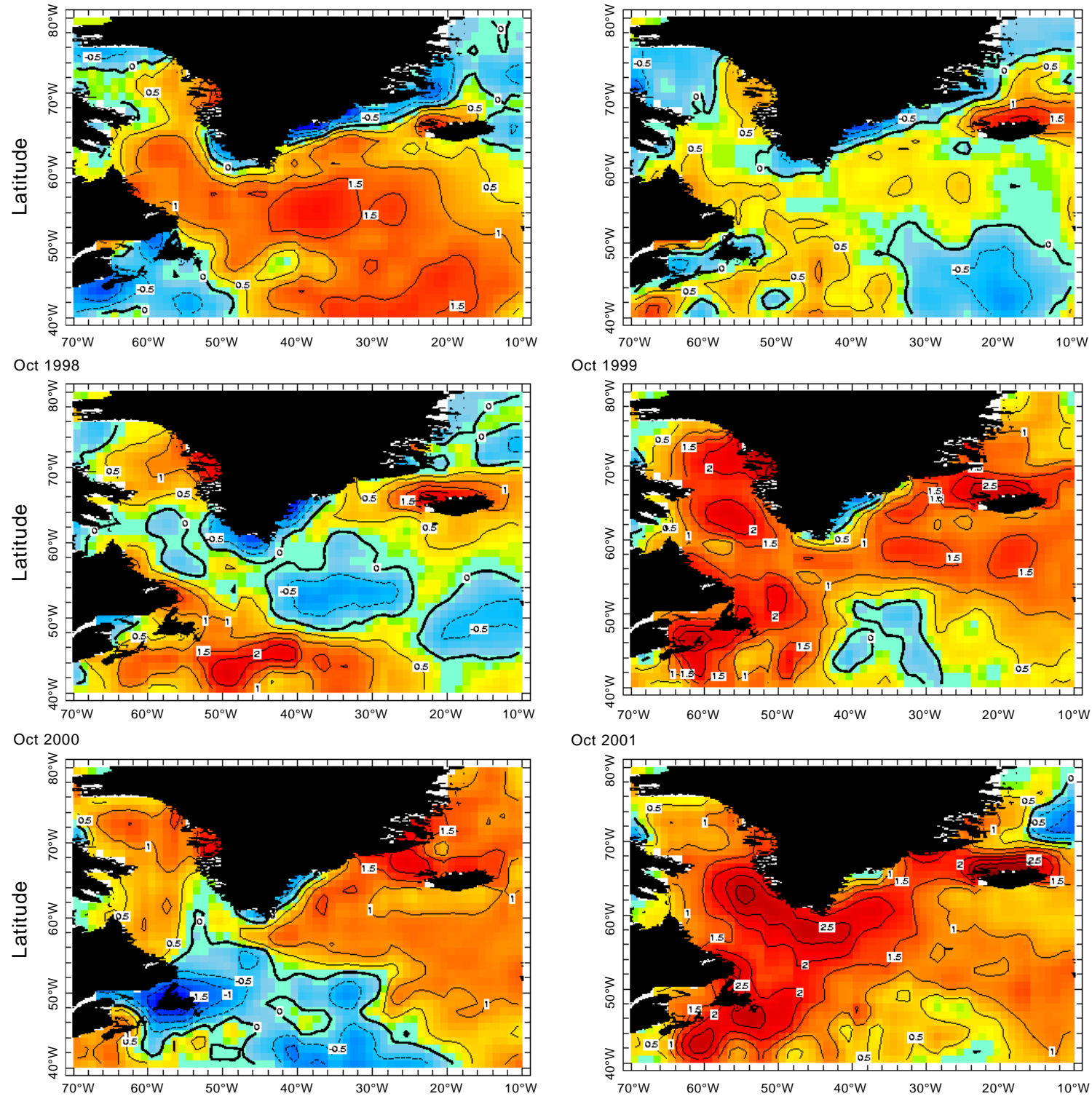

Oct 2001
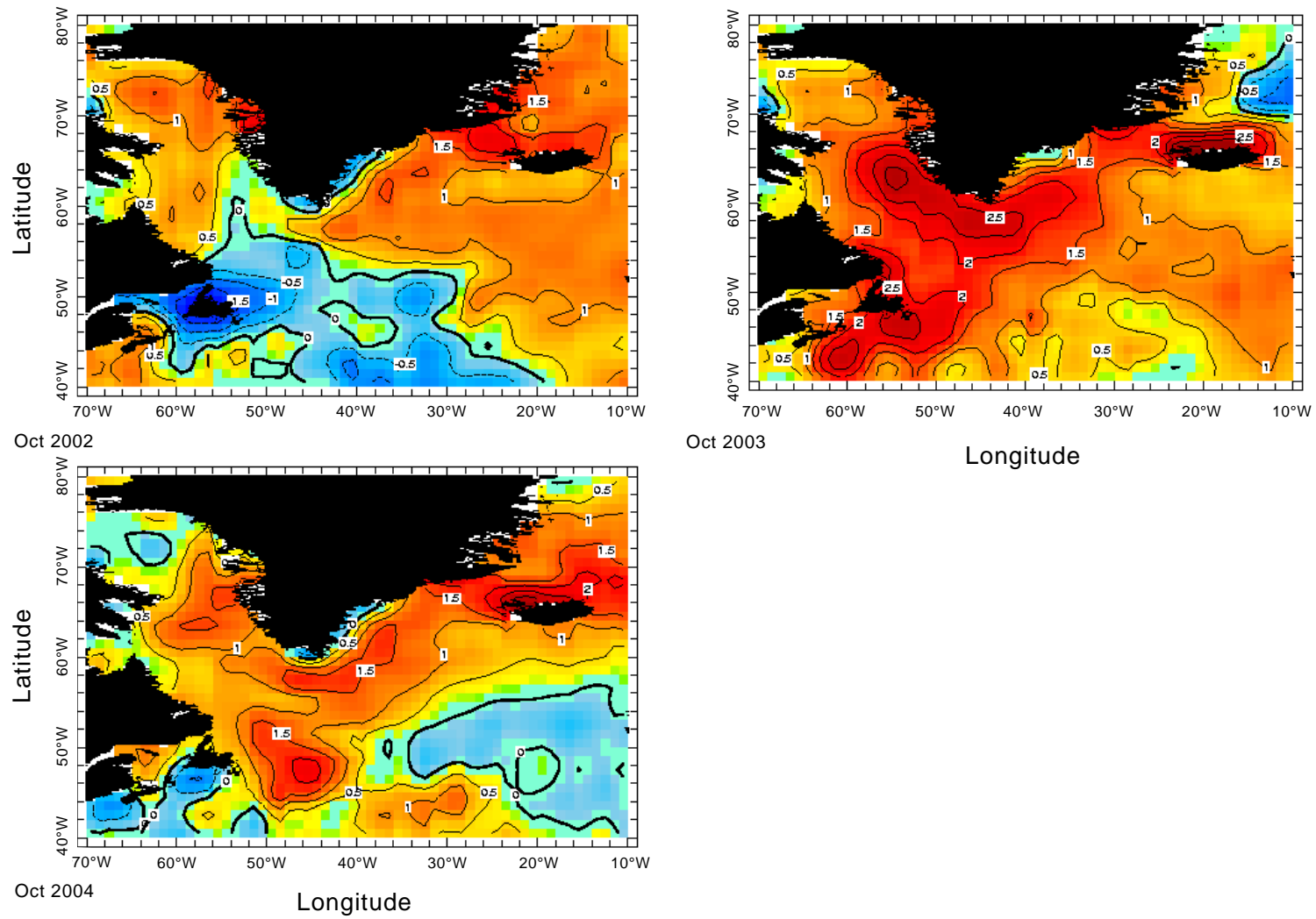

Oct 2003

Longitude

Fig. 2c. Sea-surface temperature anomalies during October $1998-2004$. Isothermal contours are in $0.5^{\circ} \mathrm{C}$ intervals. 


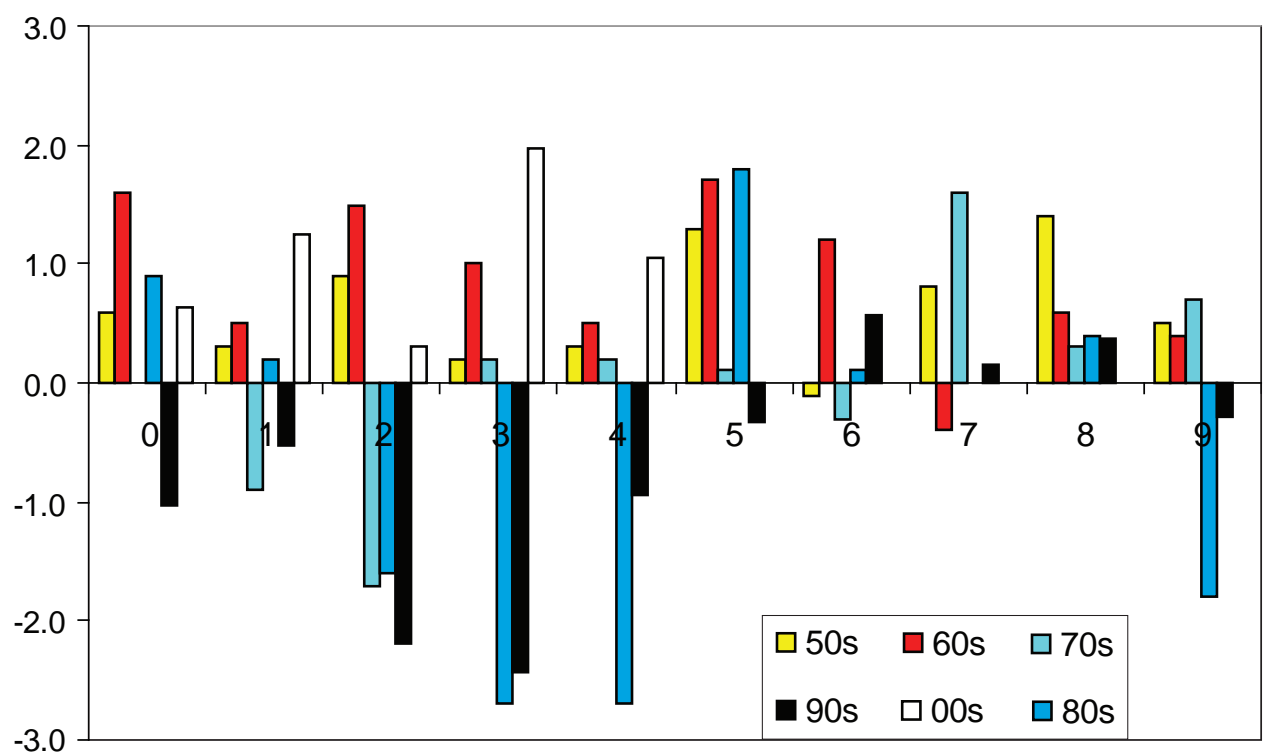

Fig. 3. Air-temperature anomalies $\left({ }^{\circ} \mathrm{C}\right)$ at Nuuk for the decades from the 1950 s to the 2000 s relative to the 1961-90 mean plotted as function of the year of the decade; data: 1950-2004.

Fyllas Bank Station 4 Temperature $\left({ }^{\circ} \mathrm{C}\right)$

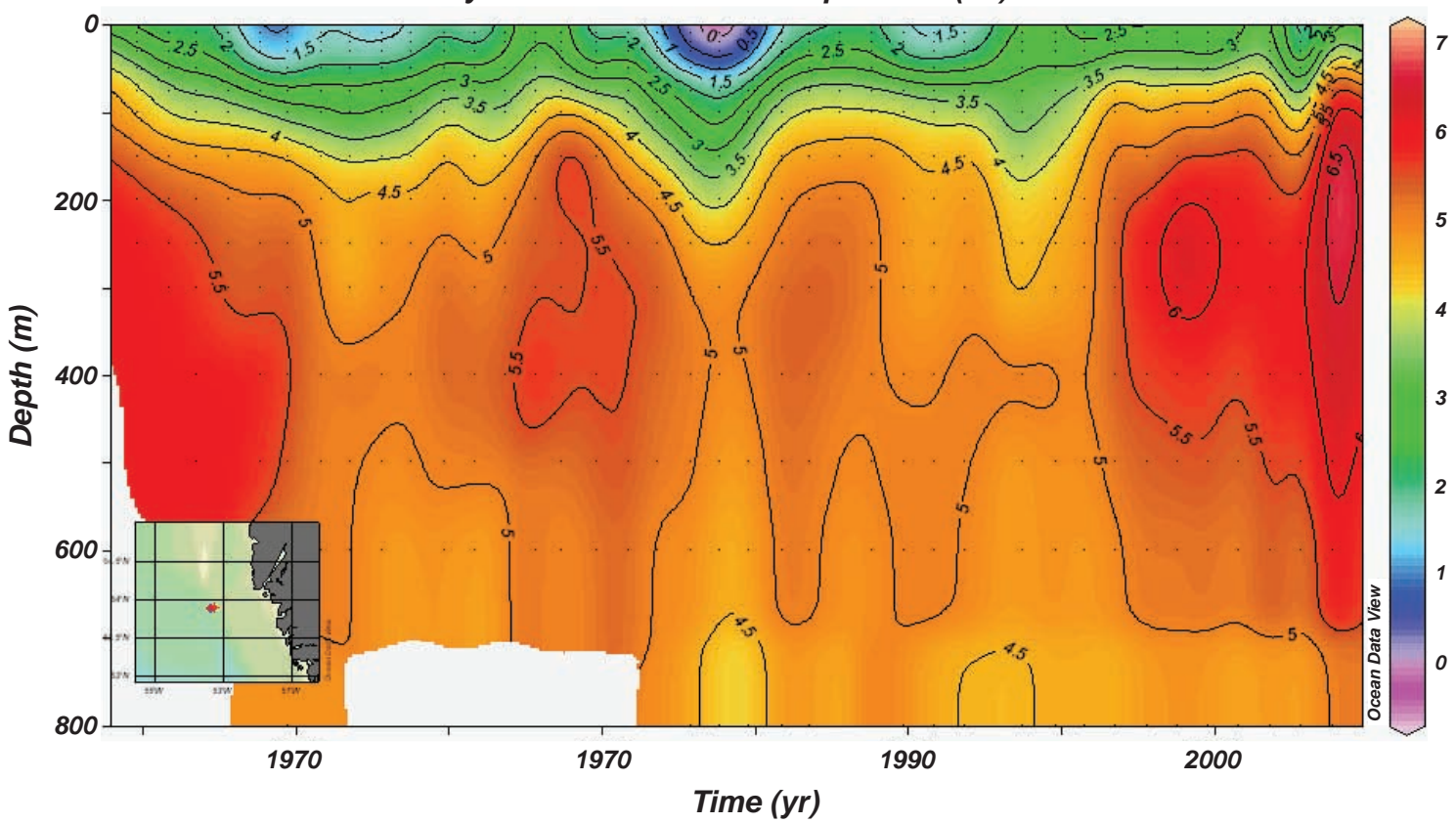

Fig. 4. Isopleth diagram of temperature at Fyllas Bank Station 4; autumn data: 1964-2004. Lower right insert shows station location.

data were interpolated to a set of common depths (ODV uses piecewise linear least squares for the interpolation on a predefined set of standard depths). Dynamic heights at the standard depths were then calculated and the geostrophic velocities between station pairs (at the standard depths) were obtained.

\section{Results}

Monthly Mean Sea-surface Temperature Anomaly (SSTA) Data

October SSTA data for the Northwest Atlantic region $\left(40^{\circ} \mathrm{N}-80^{\circ} \mathrm{N}, 70^{\circ} \mathrm{W}-10^{\circ} \mathrm{W}\right)$ reveal high variability from 
TABLE 1. Location of CTD stations along the Holsteinsborg/Baffin Island Section

\begin{tabular}{lll}
\hline \hline Station Number & Latitude & Longitude \\
\hline NAFO 1 & $66^{\circ} 53^{\prime} \mathrm{N}$ & $54^{\circ} 10^{\prime} \mathrm{W}$ \\
NAFO 2 & $66^{\circ} 50^{\prime} \mathrm{N}$ & $54^{\circ} 42^{\prime} \mathrm{W}$ \\
NAFO 3 & $66^{\circ} 46^{\prime} \mathrm{N}$ & $55^{\circ} 36^{\prime} \mathrm{W}$ \\
NAFO 4 & $66^{\circ} 43^{\prime} \mathrm{N}$ & $56^{\circ} 07^{\prime} \mathrm{W}$ \\
NAFO 5 & $66^{\circ} 41^{\prime} \mathrm{N}$ & $56^{\circ} 38^{\prime} \mathrm{W}$ \\
HUDSON 5 & $66^{\circ} 30^{\prime} \mathrm{N}$ & $57^{\circ} 40^{\prime} \mathrm{W}$ \\
HUDSON 4 & $66^{\circ} 30^{\prime} \mathrm{N}$ & $58^{\circ} 19^{\prime} \mathrm{W}$ \\
HUDSON 3 & $66^{\circ} 30^{\prime} \mathrm{N}$ & $59^{\circ} 33^{\prime} \mathrm{W}$ \\
HUDSON 2 & $66^{\circ} 30^{\prime} \mathrm{N}$ & $60^{\circ} 16^{\prime} \mathrm{W}$ \\
HUDSON 1 & $66^{\circ} 30^{\prime} \mathrm{N}$ & $60^{\circ} 50^{\prime} \mathrm{W}$ \\
\hline
\end{tabular}

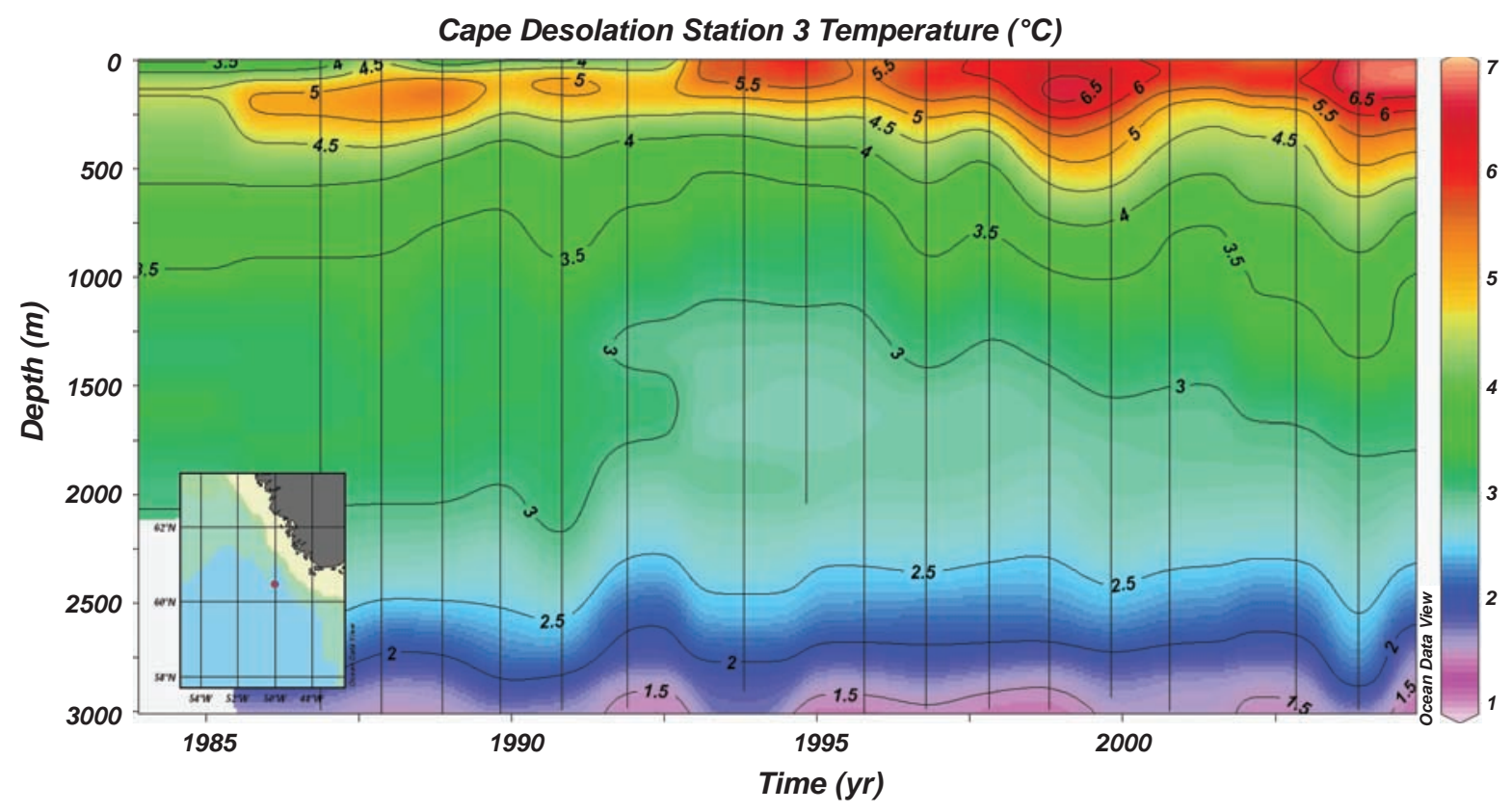

Fig. 5. Isopleth diagram of potential temperature at Cape Desolation Station 3; autumn data: 1983-2004. Lower right insert shows station location.

the 1980 s to the 2000s (Fig. 2). Colder-than-normal surface water dominated the area south and southwest off Greenland during the early-1980s (Fig. 2a). In 1985-88, offshore Greenland waters were characterized by intermediate warming. During 1989 and the early 1990s, colder-than-normal SST's were off Greenland while warmer-than-normal surface waters were observed in the southern region. From 1997 onwards, warming in the Subpolar Gyre became more evident. October 2003 conditions represented record high warming of surface waters with anomalies exceeding $3^{\circ} \mathrm{C}$ off southwest Greenland region (Fig. 2c, lower right panel).

\section{Air Temperature Anomalies from Nuuk}

Nuuk air temperature anomalies during the years 1950-2004 (Fig. 3) indicate that the 1950s (yellow) and 1960s (red) were generally warmer-than-normal decades. The 1970s (light blue), 1980s (blue) and 1990s (black) were characterized by very cold years in the first part of the decade (1971, 1972, 1982-84, 1990-94). Since 2000, 


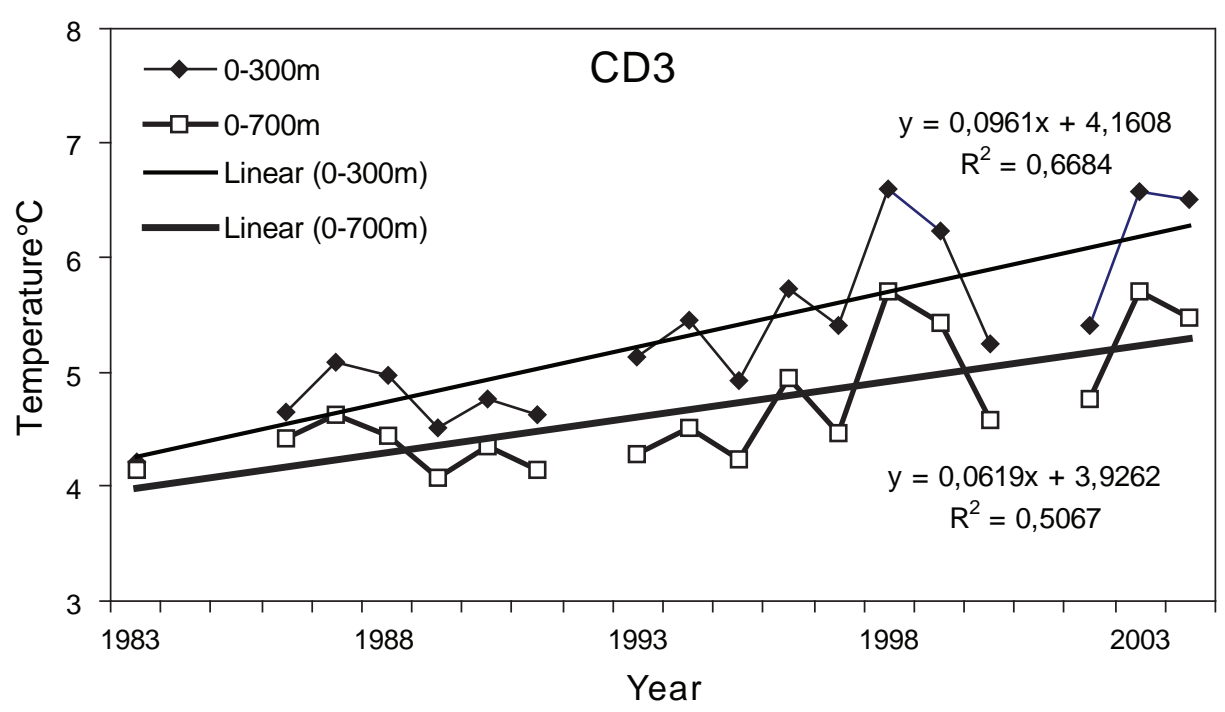

Fig. 6. Time series of temperature for 0-300 $\mathrm{m}$ and 0-700 $\mathrm{m}$ layers and their linear trends; autumn data 1983-2004.

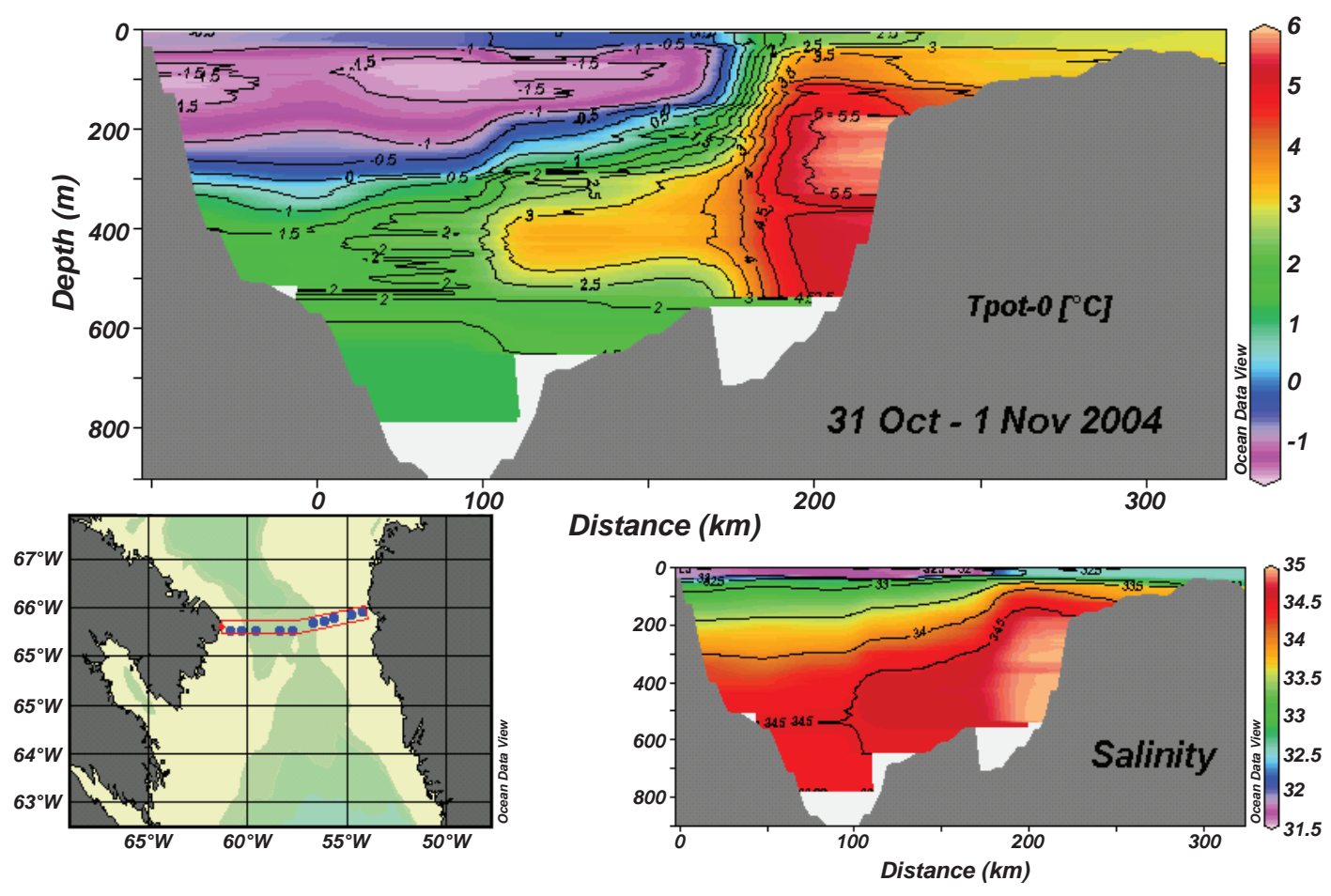

Fig. 7. Vertical distribution of temperature and salinity in Davis Strait along the Holsteinsborg-Baffin Island section; 31 October-1 November 2004. The lower left panel shows the station locations.

all years have been warmer-than-normal (red hatched columns in Fig. 3). This trend coincides with the SSTAs discussed above.

\section{Sub-surface Oceanographic Conditions}

Fyllas Bank Station 4. The autumn temperatures at Fyllas Bank station 4 reveal considerable variation during 
TABLE 2. Geostrophic volume transports from the Holsteinsborg/Baffin Island section during October in Sverdrups (- southward, + northward).

\begin{tabular}{cccc}
\hline \hline Year & Southward flow & Northward flow & Flow on WG shelf \\
\hline 1963 & -2.3 & +2.2 & +0.2 \\
1965 & -2.5 & +1.9 & no obs. \\
1988 & -2.0 & +0.5 & no obs. \\
2004 & -1.9 & +2.4 & +0.5 \\
\hline
\end{tabular}

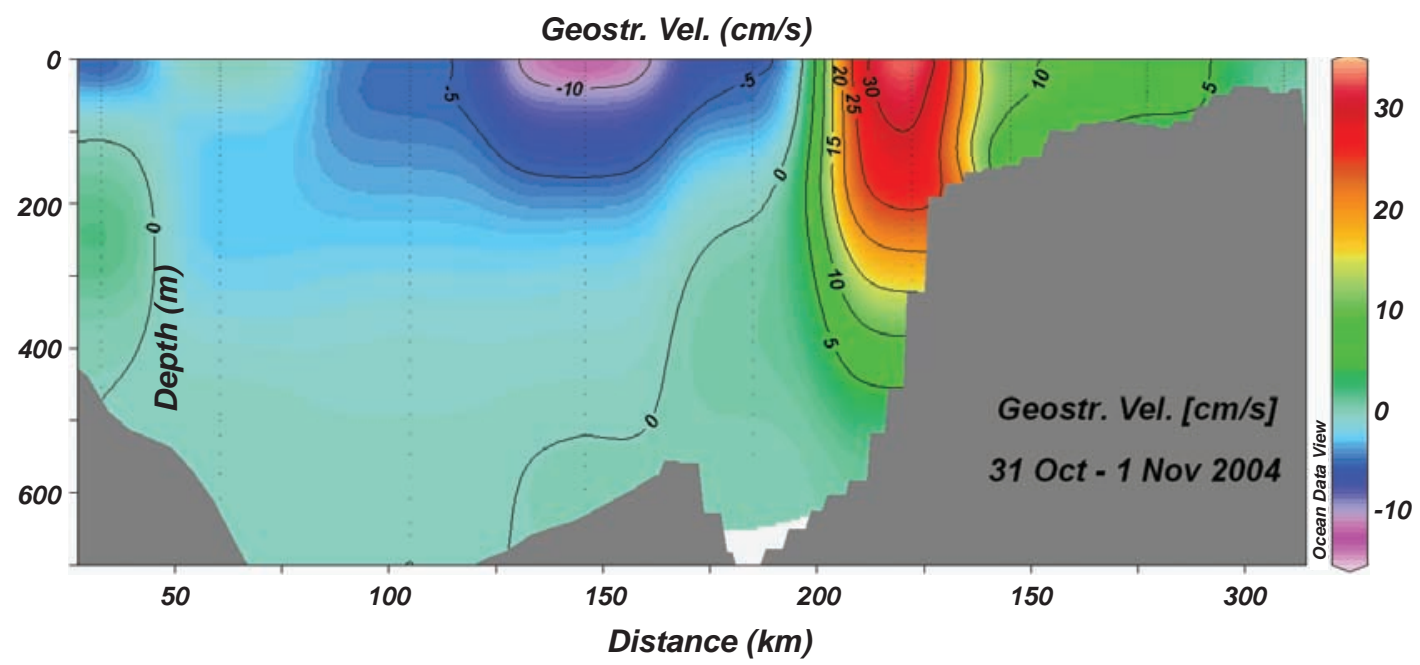

Fig. 8. Vertical distribution of geostrophic currents in Davis Strait along the Holsteinsborg-Baffin Island section; 31 October-1 November 2004.

the past decades (Fig. 4). Located on the bank slope in about $900 \mathrm{~m}$ of water, the thermal properties below $150 \mathrm{~m}$ are mostly governed by the warm component of the WGC. This warm water lies below an upper layer of colder shelf water that extends offshore. In some years, this shelf water extends far westward bring much colder-than-normal water to station 4 (e.g. events in 1983, 1992 and 2002). During 2003, record near-surface warming was observed (an anomaly of $+2.69^{\circ} \mathrm{C}$ relative to the $1963-90$ climatic mean). During the 1960s sub-surface temperatures were warmer than $5.5^{\circ} \mathrm{C}$. In the $1970 \mathrm{~s}$ (except for the late $1970 \mathrm{~s}$ ) and $1980 \mathrm{~s}$ they were around $5^{\circ} \mathrm{C}$, and from the mid-1990s onwards sub-surface warming increased with maximum temperatures during $2003\left(>6.5^{\circ} \mathrm{C}\right.$ near $\left.200 \mathrm{~m}\right)$. The depth of the warm water layer also increased considerably, from about $400 \mathrm{~m}$ to about $700 \mathrm{~m}\left(5.5^{\circ} \mathrm{C}\right.$ contour $)$.

Cape Desolation Station 3. Located further offshore than Fyllas Bank station 4, Cape Desolation station 3 has a $3000 \mathrm{~m}$ deep water column that contains several different water masses. In this paper, only the 0-700 m layer is considered. The potential temperature isopleths show warm water $\left(>4.0^{\circ} \mathrm{C}\right)$ in the upper $600-700 \mathrm{~m}$ (Fig. 5). Within this layer, temperatures changed considerably over the 22 years of observation: temperatures exceed $6^{\circ} \mathrm{C}\left(2^{\text {nd }}\right.$ half of 1990s), and $6.5^{\circ} \mathrm{C}$ during 2003 and 2004, and the vertical extension of the warm water increases from the mid-1990s onwards.

Mean temperatures for the $0-300 \mathrm{~m}$ and the $0-700 \mathrm{~m}$ layers were calculated and plotted against time (Fig. 6). The vertical dimensions of the layers were chosen to match those in Levitus et al. (2005). Our data yield a significant warming trend for the time period 1983-2004, which amounts to $0.096^{\circ} \mathrm{C}(0-300 \mathrm{~m})$ and $0.062^{\circ} \mathrm{C}(0-700 \mathrm{~m})$. The data also show more variability from 1998 onwards. Based on a much longer time series, Levitus et al. (2005) calculated a warming of $0.354^{\circ} \mathrm{C}$ during $1955-2003$ for the upper $300 \mathrm{~m}$ of the North Atlantic Basin. This is equivalent to $0.007^{\circ} \mathrm{C} \mathrm{y}^{-1}$, a value that is much lower than our $0.096^{\circ} \mathrm{C}^{-1}$ warming during $1983-2004$. The difference in warming trends may be explained by (a) the difference in the time period over which the trend was calculated, and (b) by the Subpolar Gyre regional 
warming from the mid-1990s onwards. In regards to (a), Fyllas Bank station 4 shows warm sub-surface conditions during the 1960s (see above). Applying a linear trend will result in a weaker trend going from "warm through cold to warm" conditions (1955-2003), instead of going from "cold to warm" conditions (1983-2004). In regards to (b), the Subpolar Gyre regional warming, both the Fyllas Bank station 4 and the Cape Desolation station 3 (Fig. 4, 5), indicate rapid warming of the WGC from the mid-1990s onwards. The rate of warming for the 0-300 $\mathrm{m}$ and the 0-700 $\mathrm{m}$ layers at Cape Desolation station 3 (see Fig. 6), thus point at the impact of the Subpolar Gyre regional warming.

Davis Strait temperature and salinity. There are two salient features in the vertical distribution of temperature (upper panel in Fig. 7), which characterize the hydrographic properties in Davis Strait, the Baffin Island Current and the WGC. The Baffin Island Current is a broad current band that exports cold water (core temperatures $<-1.64^{\circ} \mathrm{C}$ ) from Baffin Bay southwards. On the eastern side of the section, the WGC flows along the shelf break and transports heat (core temperatures $>5.9^{\circ} \mathrm{C}$ ) into the Baffin Bay. There is a sub-surface tongue of warm WGC water $\left(>3^{\circ} \mathrm{C}\right)$ located under the cold Baffin Island Current, which extends westward from the WGC-core. Further west, at station HUDSON 3, a remnant of $2^{\circ} \mathrm{C}$ warm water is visible (Fig. 7). A month prior to our observations, the US RV Knorr observed a sub-surface patch of warm water at this location that had thermohaline properties of WGCwater (B. Petrie, Bedford Institute of Oceanography, pers. comm.). Salinity reveals a near-surface thin layer of low saline water $(<32)$ on the western side of the section and $<33$ water on the eastern side (lower right panel of Fig. 7). In the WGC-core at the West Greenland slope, salinities are near 34.94. Similar to the vertical temperature distribution along this section there is a remnant of saline water (>34.5) below the Baffin Island Current water. Compared to mean autumn conditions, the 2004 temperatures in the WGC-core and on the West Greenland Shelf were up to $2^{\circ} \mathrm{C}$ warmer than normal.

Davis Strait geostrophic velocities. For geostrophic velocity estimates, a level of no motion was assumed at the bottom for all analysed data sets (1963, 1965, 1988 and 2004). The vertical distribution of relative current speeds along the section across Davis Strait and the West Greenland Shelf is given in Fig. 8 for the October 2004 measurements. The Baffin Island Current had surface speeds ranging from $0.10-0.16 \mathrm{~ms}^{-1}$, whereas in the WGC they were $0.10-0.36 \mathrm{~ms}^{-1}$. About $180 \mathrm{~km}$ of the Baffin Island/Holsteinsborg section $(330 \mathrm{~km})$ was dominated by the Baffin Island Current $\left(\leq 0.12 \mathrm{~ms}^{-1}\right)$ during 2004 , while the WGC $\left(\leq 0.36 \mathrm{~ms}^{-1}\right)$ was concentrated at the shelf break off West Greenland (Fig. 8). On the West Greenland Shelf, current velocities amounted to about $0.10 \mathrm{~ms}^{-1}$ during 2004. The warm WGC water located under the cold Baffin Island Current $\left(>3^{\circ} \mathrm{C},>34.5\right.$; see above) flowed south at between $0.003 \mathrm{~m} \mathrm{~s}^{-1}$ and $0.01 \mathrm{~m} \mathrm{~s}^{-1}$, which points to a return flow of modified WGC water.

Davis Strait volume fluxes. The geostrophic velocity profiles as discussed above, form the basis for the volume transport computations. Table 2 lists the geostrophic volume transports for October 1963, 1965, 1988 and 2004. Time series of temperature from Fyllas Bank (Fig. 4) indicate that the 1960s were among the warmest years off West Greenland. Sub-surface thermal conditions revealed similar warm conditions after the mid-1990s. The subsurface temperatures during the 1970s and 1980s were relatively cold. The volume fluxes through Davis Strait thus cover warm, cold and the near warmest (2004) conditions. The "northward" volume transports as given in Table 2 indicate maximum values for 2004, both in the core of the WGC and on the West Greenland shelf, amounting to $+2.9 \mathrm{~Sv}\left(1 \mathrm{~Sv}=1\right.$ Sverdrup $\left.=10^{6} \mathrm{~m}^{3} \mathrm{~s}^{-1}\right)$. During 1963 and 1965, when there was both warmer-than-normal air and subsurface ocean temperatures (Buch et al, 2004), the northward flow was $+2.2 \mathrm{~Sv}$ and $+1.9 \mathrm{~Sv}$, respectively, and the northward transport on the West Greenland shelf was $+0.2 \mathrm{~Sv}$ during 1963 . The 1988 data show an unusually low northward transport and there is a counter flow $(-0.3 \mathrm{~Sv})$ eastwards of the WGC core. The southward flow ranges from -1.9 Sv during 2004 to $-2.5 S v$ during 1965.

\section{Summary and Discussion}

Using monthly mean sea-surface temperature anomaly data for the Northwest Atlantic, recent observations from NAFO Standard Stations Fyllas Bank 4 and Cape Desolation 3, as well as from a newly formed hydrographic section across Davis Strait passage, and historic data from Davis Strait, it is shown that the observed warming of the North Atlantic Subpolar Gyre had a tremendous impact on West Greenland Shelf and off-slope waters. While sea-surface temperature warming and sub-surface ocean temperature warming seem to have peaked during 2003 , the year with warmest mean annual air temperatures at Nuuk since 1950, the long-term trend as observed in the temperature time series of the upper $300 \mathrm{~m}$ of the ocean off southwest Greenland suggests further warming maybe in store.

As a result of Subpolar Gyre warming, the WGC transported more heat northward than usually. The volume transport figures (Table 2) indicate that the baroclinic part 
of the northward transport through Davis Strait increased considerably and is in the upper range of the monthly mean volume transport values as deduced from mooring data (Cuny et al., in press) for October (+ 1.6 Sv) and November $(+3.0 \mathrm{~Sv})$. The current speeds obtained for the West Greenland Shelf amount to $0.10 \mathrm{~ms}^{-1}$, a value that agrees well with surface drifter measurements (Cuny et al., 2002). All data on southward transports, the historic data from 1963, 1965 and 1988, as well as our recent measurements during autumn 2004 (see Table 2) are considerably lower than those published in the literature for mean annual transports for Davis Strait, excluding the West Greenland Shelf: $-4.6 \pm 1.1$ Sv (Cuny et al., in press), - 3.3 Sv (Loder et al., 1998), - 3.1 Sv (Ross, 1992). The significant differences in published results and this paper's southward transport figures are most likely caused by different assumptions and different estimation methods. Cuny et al. (in press) explain their differences with the Loder and Ross data by differences in the assumptions for the top $150 \mathrm{~m}$ of the water column. (Loder et al., 1998) and (Ross, 1992) considered no velocity shear in the top $150 \mathrm{~m}$ which makes a significant difference (Cuny et al., in press). The published data took moored velocity data into account (Cuny et al., in press), while data in this paper represents solely the geostrophic component of the flow.

\section{References}

BUCH, E. 2000. Air-sea-ice conditions off Southwest Greenland, 1981-97. J. Northw. Atl. Fish. Sci., 26: 123-136.

BUCH, E., S. A. PEDERSEN, and M. H. RIBERGAARD. 2004. Ecosystem variability in West Greenland waters. J. Northw. Atl. Fish. Sci., 34: 13-28.
CUNY, J., P. B. RHINES, and R. KWOK. 2005. Davis Strait volume, freshwater and heat fluxes. Deep-Sea Res., (in press).

CUNY, J., P. B. RHINES, P. P. NIILER, and S. BACON. 2002. Labrador Sea boundary currents and the fate of the Irminger Sea Water. J. Phys. Oceanogr. 32: 627-647.

DRINKWATER, K. F. 2004. Atmospheric and sea-ice conditions in the Northwest Atlantic during the decade, 1991-2000. J. Northw. Atl. Fish. Sci., 34: 1-11.

HÄKKINEN, S., and P. B. RHINES. 2004. Decline of Subpolar North Atlantic circulation during the 1990s. Science, 304: 555-559.

LEVITUS, S., J. ANTONOV, and T. BOYER. 2005. Warming of the world ocean, 1955-2003. Geophys. Res. Lett., 32, L02604, doi:10.1029/2004GL021592.

LODER, J. W., B. PETRIE, and G. GAWARKIEWICZ. 1998. The coastal ocean off Northeastern North America: A largescale view. In: The Sea. Robinson, A.R., and K. H. Brink (eds.), Vol. 11. John Wiley and Sons, p. 105-133.

PRATER, M. D. 2002. Eddies in the Labrador Sea as observed by profiling RAFOS floats and remote sensing. J. Phys. Oceanogr., 32: 411-457.

REYNOLDS, R.W., and T. M. SMITH. 1994. Improved global sea-surface temperature analyses. J. Climate, 7: 929-948.

ROSS, C. 1992. Moored current meter measurements across Davis Strait. NAFO SCR Doc., No. 70, Serial No. N2124, $8 \mathrm{p}$.

SCHLITZER, R. 2004. Ocean Data View. http://www.awibremerhaven.de/GEO/ODV.

STEIN, M. 1988. Revision of list of NAFO standard oceanographic sections and stations. NAFO SCR Doc., No. 1, Serial No. N1432, 9 p.

2004. Climatic overview of NAFO Subarea 1, 19912000. J. Northw. Atl. Fish. Sci., 34: 29-41.

2005. Climatic conditions around Greenland - 2004. NAFO SCR Doc., No. 2, Serial No. N5075, 20 p. 